\title{
Pengaruh Dosis Urea Terhadap Pertumbuhan Dan Hasil Kedelai (Glycine max L) Varietas Dena 1 Dan Devon 1
}

\author{
Aditya Murtilaksono1), Amarullah ${ }^{1)}$, Eko Hary Pudjiwati1), Nurmaisah ${ }^{1}$, Samjon ${ }^{2}$, \\ Eso Solihin ${ }^{3}$ dan Haris Maulana ${ }^{4)}$ \\ 1)Program Studi Agroteknologi, Fakultas Pertanian, Universitas Borneo Tarakan, Kalimantan Utara \\ 2)Balai Penyuluh Pertanian. Dinas Pertanian, Pertenakan dan Perikanan,Kabupaten Malinau, \\ Kalimantan Utara, Indonesia \\ 3)Departemen Ilmu Tanah dan Sumberdaya Lahan, Fakultas Pertanian Universitas Pajadjaran \\ 4) Departemen Budidaya Pertanian, Fakultas Pertanian, Universitas Padjadjaran.
}

Korespondensi: aditwalker02@gmail..com

\begin{abstract}
One of the problems on soybean production in North Kalimantan is the acidic soil conditions. The use of soybean varieties that are resistant to acidic soil conditions is an alternative to overcome this problems. Dena 1 and Devon 1 soybeans were the varieties that can be grown in acid soils. In addition to the right seeds, application of fertilizer is also needed to support the growth and grain yield of soybean. This study aimed to determine the interaction between varieties with Urea dosage on growth and grain yield of soybean varieties Dena 1 and Devon 1. The experimental design of this study was factorial randomized block design with two factors. The first factor was the soybean variety which consisted of: V1 = Devon 1 and V2 = Dena 1. The second factor was the Urea fertilizer dosage which consisted of four levels: $P 0=$ Control, $P 1=1.32 \mathrm{~g} /$ plant, $P 2=2.64 \mathrm{~g} / \mathrm{plant}, P 3=5.28 \mathrm{~g} /$ plant. The results showed that there were no interaction between varieties and the Urea fertilizer dosage on growth and grain yield of soybeans. However, the variety independently had a significant effect on plant height and leaf width, which was shown by the Dena1 (V2) treatment.
\end{abstract}

Keywords: nitrogen, growth, soybean, yield

\section{PENDAHULUAN}

Kedelai sudah cukup lama dibudidayakan di Indonesia. Tanaman ini termasuk komoditas pangan stategis setelah padi dan jagung, sehingga termasuk sebagai komoditas utama dalam pengembangan tanaman pangan (Winarso, 2013). Kedelai saat ini banyak dijadikan sebagai olahan bahan pangan seperti tempe, tahu dan susu. Hal ini yang membuat kedelai semakin banyak diminati. Namun seiring dengan peningkatan jumlah penduduk membuat permintaan kedelaipun semakin meningkat. Menurut BPS (2016), produksi kedelai nasional berjumlah 963,18 ribu ton jumlah ini hanya dapat memenuhi 38\% dari kebutuhan yang diperlukan. Salah satu yang menjadi penyebab rendahnya produksi kedelai adalah belum menggunakannya benih kedelai varietas unggul dan pemupukan yang belum berimbang.

Indonesia memiliki \pm 80 varietas unggul kedelai (Balitkabi, 2015). Varietas unggul tersebut diantaranya memiliki keragaman spesifik seperti umur panen (genjah/hibrida), ukuran biji, hasil panen, ketahanan cekaman terhadap lingkungan tertentu, ketahanan terhadap hama dan penyakit, dll (Susanto dan Nugrahaeni, 2017). Varietas unggul kedelai yang berkarakter tahan terhadap hama dan penyakit diantaranya Dena 1 dan Devon 1 . Berdasarkan potensi produksinya, Devon 1 lebih tinggi dari Dena 1 (Balitkabi, 2015).

Penggunaan varietas unggul memegang peranan sangat penting dalam mendukung perkembangan tanaman. Selain itu, varietas unggul juga merupakan teknologi yang lebih disukai oleh petani (Arsyad dkk., 2013). Varietas unggul telah menjadi jaminan terhadap produktivitas tanaman yang tinggi. Namun, pada prinsipnya, produktivitas tanaman di lapangan dipengaruhi oleh interaksi antara faktor genetik dari varietas dengan kondisi lingkungan tumbuh. Bila lingkungan tumbuh tidak dikelola dengan baik maka potensi hasil yang tinggi dari varietas unggul tersebut tidak dapat tercapai (Adisarwanto, 2005). 
Upaya perbaikan lingkungan tumbuh dapat dilakukan dengan memperbaiki kualitas media tanam. Pemupukan telah lama dikenal sebagai teknologi yang efektif dalam meningatkan unsur hara dalam tanah dan meningkatkan produktivitas tanaman. Tanaman kedelai sebagaimana tanaman pangan lainnya membutuhkan unsur hara Nitrogen. Jumlah nitrogen yang dibutuhkan oleh tanaman kedelai berbeda-beda, tergantung kepada varietasnya (Taufiq dan Sundari, 2012).

Pemberian pupuk nitrogen urea pada tanaman akan meningkatkan pertumbuhan vegetatif tanaman seperti jumlah daun lebih banyak, daun akan lebih lebar dan warna daun akan lebih hijau. Menurut hasil penelitian Permanasari dkk (2014) tanaman kedelai yang diberikan pupuk urea sebanyak $2 \mathrm{~g}$ pertanaman mampu meningkatkan jumlah daun. Triadiati dkk (2013) menambahkan bahwa tanaman kedelai yang diberikan 5 g urea pertanaman dapat meningkatkan lebar daun.

Tujuan dari penelitian ini yaitu mengetahui pengaruh dosis Urea terhadap pertumbuhan dan hasil kedelai varietas Dena 1 dan Devon 1. Dalam hal ini pengujian dilakukan terhadap respon masing-masing varietas terhadap dosis pemupukan urea sebagai sumber Nitrogen. Hasil yang diharapkan adalah sebuah rekomendasi mengenai kombinasi varietas unggul kedelai dan dosis pupuk urea yang dapat memberikan hasil kedelai tertinggi.

\section{BAHAN DAN METODE}

Penelitian ini dilaksanakan pada bulan November 2018 hingga Februari 2019 di Kebun Asrama Katolik Santo Eugenius De Mazenod Kelurahan Pantai Amal Kota Tarakan. Benih kedelai yang digunakan dalam penelitian ini yaitu varietas Dena 1 dan Devon 1 merupakan koleksi BALITKABI Malang. Varietas ini merupakan hasil persilangan. Varietas Dena 1 hasil persilangan antara varietas Agromulyo $x$ IAC 100. Varietas Devon 1 hasil persilangan antara varietas Kawi x IAC 100. Benih kedelai yang ditanam memiliki vigor yang baik, dimana memiliki daya tumbuh lebih dari $80 \%$.
Alat yang digunakan dalam penelitian ini adalah cangkul, thermo-hygrometer, parang, meteran, penggaris, sandak, skop, jaring-jaring, plastik label, ember, tali rapia, kamera, handspreyer, timbangan analitik, jangka sorong, gelas ukur, soiltester, klorofil meter (SPAD) dan oven. Bahan yang digunakan dalam penelitian ini adalah benih kedelai varietas Devon 1 dan varietas Dena 1, air, pupuk kandang ayam dan pupuk urea.

Rancangan penelitian ini disusun dengan menggunakan Rancangan Acak Kelompok (RAK) dengan dua faktor. Faktor pertama varietas (V) terdiri dari 2 taraf yaitu: V1 = Devon 1, V2 = Dena 1. Faktor kedua dosis pupuk Urea (P) terdiri dari 4 taraf: $\mathrm{P} 0=$ Kontrol, $\mathrm{P} 1=1,32 \mathrm{~g}$ Urea per tanaman, P2 $=2,64$ g Urea per tanaman, P3 = 5,28 g Urea per tanaman. Dengan demikian diperoleh 8 kombinasi perlakuan. Perlakuan tersebut diulang 4 kali, sehingga diperoleh 32 satuan percobaan.

Penelitian dimulai dengan membersihkan gulma di lahan kemudian mengukur luas lahan yang digunakan dalam penelitian dengan menggunakan meteran setelah itu dilakukkan pengolahan tanah. Pengolahan tanah pada tanaman kedelai dilakukan dengan cara mencangkul tanah. Pengolahan tanah ini dilakukan 1 minggu sebelum tanam. Selanjutnya dibuat bedengan dengan ukuran 1 $\mathrm{x} 1$ meter dengan ketinggian bedengan $40 \mathrm{~cm}$.

Penanaman dilakukan pada bedengan berukuran $1 \mathrm{x} 1$ meter dengan jarak tanam $25 \mathrm{x}$ $25 \mathrm{~cm}$. Penamanan kedelai dilakukan dengan sistem tugal dengan kedalaman tanam $3 \mathrm{~cm}$. Setiap lubang diisi 3 benih kemudian ditutup dengan tanah. Setelah tanaman berumur 2 minggu selanjutnya dilakukan penjarangan pada tanaman kedelai dan hanya terdapat 1 tanaman per lubang tanam.

Pemupukan dilakukan 2 kali yaitu pemupukan dasar menggunakan pupuk kotoran ayam dan pemupukan perlakuan menggunakan pupuk Urea. Pemupukan dasar dilakukan satu minggu sebelum tanam dengan dosis 5 ton per hektar atau 31,25 g per tanaman. Pemupukan perlakuan dilakukan dua kali yaitu 
pemupukan pertama diberikan pada umur tanaman kedelai 7 HST sebanyak $1 / 2$ dosis perlakuan per tanaman. Pemberian pemupukan kedua diberikan pada umur tanaman kedelai 30 HST sebanyak $1 / 2$ dosis perlakuan.

Penyiraman dilakukan pada saat tidak ada hujan dilakukan di sore hari dengan melihat kelembaban tanah di atas 80\% menggunakan soiltester dan memberikan air dengan takaran yang sama yaitu 6,3 mm per tanaman (Yuliawati dkk., 2014). Penyiangan dilakukan dengan cara mencabut gulma. Pembumbunan dilakukan secara manual yaitu menggunakan cangkul untuk menggemburkan tanah di sekitar tanaman kedelai.

Parameter vegetatif diamati pada umur 35 HST meliputi tinggi tanaman, jumlah daun, lebar daun. Parameter generatif diamati pada umur 83 HST meliputi berat kering kedelai, berat polong kedelai, jumlah polong kedelai, berat biji per tanaman, berat biji per hektar.

Tanaman kedelai dipanen pada waktu yang bersamaan yaitu pada umur tanaman 83 HST. Ciri-ciri tanaman kedelai yang siap dipanen yaitu dapat dilihat dari daun dan polong mulai menguning kecoklatan. Panen dilakukan dengan cara mengambil polong kedelai pertanaman pada setiap bedengan

Data yang telah diperoleh dari lahan penelitian selanjutnya dianalisis menggunakan Analisis Sidik Ragam (ANOVA) dengan taraf 95\% kemudian dilanjutkan dengan uji Duncan Multiple Range Test (DMRT) dengan taraf kepercayaan 5\% untuk mengetahui perbedaan antar perlakuan.

\section{HASIL DAN PEMBAHASAN}

\subsection{Pertumbuhan Tanaman pada 35 HST}

\subsubsection{Tinggi Tanaman}

Hasil analisis statistik menunjukan bahwa perlakuan varietas dan pemberian dosis pupuk urea terhadap tinggi tanaman tidak menunjukkan pengaruh nyata. Namun pengaruh mandiri dari masing-masing perlakuan menunjukan hasil yang berbeda nyata untuk perlakuan varietas (Tabel 1), sedangkan untuk perlakuaan pemupukan urea tidak memberikan pengaruh yang nyata.

Tabel 1 Rata-Rata Tinggi Tanaman (cm) Tanaman Kedelai Umur 35 HST

\begin{tabular}{lc}
\hline \multicolumn{1}{c}{ Perlakuan } & $\begin{array}{c}\text { Rataan Tinggi } \\
\text { Tanaman } \\
(\mathrm{cm})\end{array}$ \\
\hline Varietas & $46,06 \mathrm{a}$ \\
V1= Devon1 & $53,93 \mathrm{~b}$ \\
V2= Dena 1 & $49,63 \mathrm{a}$ \\
\hline Pupuk & $49,74 \mathrm{a}$ \\
P0 = Kontrol & $50,95 \mathrm{a}$ \\
P1 = 1,32 g Urea per tanaman & $49,66 \mathrm{a}$ \\
P2 = 2,64 g Urea per tanaman & \\
P3 = 5,28 g Urea per tanaman & \\
\hline Keterangan: Angka yang diikuti huruf yang sama \\
dalam kolom, menunjukkan tidak \\
berbeda nyata berdasarkan uji DMRT \\
taraf 5\%.
\end{tabular}

Perlakuan varietas Dena1 (V2) menunjukan hasil yang berbeda nyata dibandingkan dengan perlakuan Devon1 (V1) dengan tinggi rata-rata $53,93 \mathrm{~cm}$ untuk Dena1 dan 46,06 cm untuk Devon1. Berdasarkan deskripsi varietasnya (Balitkabi, 2015), Dena1 memiliki potensi tinggi tanaman 59,0 cm, dimana lebih tinggi dari tinggi tanaman varietas Devon1 yaitu: $58,1 \mathrm{~cm}$. Tinggi tanaman adalah salah satu parameter partumbuhan kedelai yang dipengaruhi oleh varietas (Shorter \& Norman, 1982 dalam Widiastuti dan Latifah, 2016). Rataan tinggi kedelai varietas Dena 1 yang mendekati deskripsi varietasnya, hal ini menunjukkan bahwa varietas tersebut lebih sesuai dibudidayakan di lokasi penelitian dibandingkan Devon 1. Pada kondisi tanah seragam, maka pertumbuhan tanaman akan dipengaruhi faktor lingkungan lain seperti penyinaran matahari, suhu, dan kelembaban udara (Taufiq dan Sundari, 2012).

Perlakuan pupuk urea pada tanaman kedelai tidak menunjukan perbedaan yang nyata terhadap tinggi tanaman. Tanaman kedelai melalui simbiosis dengan rhizobium mampu menambat $\mathrm{N}_{2}$ dari udara. Sekitar $50 \%$ kebutuhan $\mathrm{N}$ tanaman dapat dipenuhi dari proses penambatan $\mathrm{N}_{2}$ oleh rhizobium (Salvagiotti, et. al., 2008 dalam Taufiq dan Sundari, 2012). 


\subsubsection{Jumlah Daun}

Berdasarkan hasil analisis ragam yang dilakukan menunjukan bahwa perlakuan varietas dan pemberian pupuk urea tidak menunjukan pengaruh nyata terhadap jumlah daun. Demikian pula hasil pengujian pengaruh mandiri baik dari varietas maupun perlakuan dosis urea tidak memberikan pengaruh nyata terhadap jumlah daun (Tabel 2).

Tabel 2 Rata-Rata Jumlah Daun (Helai) Tanaman Kedelai 35 HST

\begin{tabular}{lc}
\hline \multicolumn{1}{c}{ Perlakuan } & $\begin{array}{c}\text { Rataan } \\
\text { Jumlah Daun } \\
\text { (Helai) }\end{array}$ \\
\hline Varietas & \\
V1= Devon1 & $25,01 \mathrm{a}$ \\
V2= Dena 1 & $26,46 \mathrm{a}$ \\
\hline Pupuk & \\
P0 = Kontrol, & $24,01 \mathrm{a}$ \\
P1 = 1,32 g Urea per tanaman & $27,93 \mathrm{a}$ \\
P2 = 2,64 g Urea per tanaman & $25,92 \mathrm{a}$ \\
P3 = 5,28 g Urea per tanaman & $25,05 \mathrm{a}$ \\
\hline Keterangan: Angka yang diikuti huruf yang sama & \multicolumn{2}{l}{ dalam kolom, menunjukkan tidak } \\
\multicolumn{2}{l}{ berbeda nyata berdasarkan uji DMRT } \\
\multicolumn{2}{l}{ taraf 5\%. }
\end{tabular}

Pengamatan perlakuan varietas terhadap jumlah daun tanaman kedelai dilakukan pada 35 HST hasilnya menunjukan tidak ada perbedaan yang nyata antara varietas Devon1 (V1) dan Dena1 (V2). Hal ini tidak sesuai dengan hasi penelitian Widiastuti dan Latifah (2016) yang menyatakan bahwa jumlah daun dipengaruhi oleh varietas tanaman kedelai. Namun, hal ini kemungkinan disebabkan oleh perbedaan varietas kedelai yang digunakan.

Faktor genetik juga menjadi pertimbangan terhadap jumlah daun tanaman kedelai. Hal ini diungkapkan oleh Suhre et. al. (2014); De Bruin \& Pedersen (2008) dalam Santana dkk. (2021), dimana jumlah daun dan jumlah cabang merupakan karakter spesifik dari masing-masing varietas kedelai. Penelitian lebih lanjut diperlukan untuk memperoleh kejelasan mengenai kedekatan galur dari kedua varietas ini.

Perlakuan dosis pupuk urea tidak berpengaruh nyata terhadap jumlah daun tanaman kedelai. Hal yang sama berlaku juga pada tanaman lain seperti yang diungkapkan oleh Lina dkk (2009). Nitrogen erat kaitannya dengan sintesis klorofil (Sallisburry dan Ross, 1995), dan tidak banyak mempengaruhi jumlah daun.

Berdasarkan perbandingan dengan parameter tinggi tanaman. Dosis pupuk nitrogen tidak berpengaruh terhadap tinggi tanaman dan jumlah daun. Hal ini sejalan dengan dengan hasil penelitian Widiastuti dan Latifah (2016) yang menyatakan bahwa tinggi tanaman berkorelasi positif walau tidak signifikan dengan jumlah daun kedelai. Penilaian terhadap kadar nitrogen dalam tanah diperlukan agar pembahasan lebih komprehensif.

\subsubsection{Lebar Daun}

Berdasarkan hasil analisis ragam pada Tabel 3, perlakuan varietas berpengaruh secara mandiri terhadap lebar daun, sedangkan dosis pupuk Urea tidak berpengaruh nyata terhadap lebar daun. Varietas Dena 1 (V2) menunjukkan ukuran daun yang lebih lebar yaitu $8,42 \mathrm{~cm}$ dari varietas Devon 1 dengan nilai rataan $7,80 \mathrm{~cm}$. Berdasarkan deskripsi varietasnya, Dena 1 dan Devon 1 mempunyai ukuran daun sedang (Balitkabi, 2015). Perbedaan ukuran lebar daun menunjukkan perbedaan respons tanaman pada kedua varietas berbeda. Kedelai Dena 1 dinilai lebih responsif terhadap faktor lingkungan dibandingkan dengan kedelai varietas Devon 1.

Tabel 3 Rata-Rata Lebar Daun (cm) Tanaman Kedelai 35 HST

\begin{tabular}{lc}
\hline \multicolumn{1}{c}{ Perlakuan } & $\begin{array}{c}\text { Rataan Lebar } \\
\text { Daun }(\mathrm{cm})\end{array}$ \\
\hline Varietas & \\
V1= Devon1 & $7,80 \mathrm{a}$ \\
V2= Dena 1 & $8,42 \mathrm{~b}$ \\
\hline Pupuk & \\
P0 $=$ Kontrol, & $8,10 \mathrm{a}$ \\
P1 $=$ 1,32 g Urea per tanaman & $8,36 \mathrm{a}$ \\
P2 $=$ 2,64 g Urea per tanaman & $8,25 \mathrm{a}$ \\
P3 $=$ 5,28 g Urea per tanaman & $7,73 \mathrm{a}$
\end{tabular}

Keterangan: Angka yang diikuti huruf yang sama dalam kolom, menunjukkan tidak berbeda nyata berdasarkan uji DMRT taraf $5 \%$. 
Perlakuan dosis pupuk urea tidak berpengaruh nyata terhadap ukuran daun (lebar daun). Hal ini dapat disebabkan oleh beberapa hal, yakni dari fungsi nitrogen dan faktor ketersediaan nitrogen dalam tanah. Menurut Marschner (1986) nitrogen berperan dalam meningkatkan warna hijau daun, dan perkembangan daun. Ketersediaan nitrogen pada lahan yang ditanami kedelai akan tinggi, karena populasi Rhizobium yang tinggi (Taufiq dan Sundari, 2012). Hal ini menjadi indikasi ketersediaan nitrogen yang cukup untuk memenuhi kebutuhan tanaman kedelai.

\subsection{Hasil Kedelai}

Hasil analisis ragam menunjukan bahwa perlakuan varietas kedelai dan dosis pupuk urea tidak berpengaruh nyata terhadap berat biji kedelai. Hasil pengujian pengaruh mandiri juga menunjukkan hal yang sama, dimana baik varietas maupun dosis pupuk tidak berpengaruh nyata terhadap hasil panen (berat biji) kedelai (Tabel 4). Hal yang sama dinyatakan oleh Bachtiar dkk (2016). Menurut Balitkabi (2015), nilai rata-rata potensi hasil Dena 1 dan Devon1 adalah 2,90 ton ha-1 dan 3,09 ton ha-1. Jika dilihat dari hasil potensi produksi untuk varietas Dena1 dan Devon1 sudah melebihi potensi hasil. Hal ini menunjukkan bahwa kedua varietas tersebut sesuai dibudidayakan di lokasi penelitian.

Morfologi tanaman seperti tinggi tanaman dan jumlah batang dapat dipertimbangkan sebagai indikasi dalam pendugaan hasil tanaman kedelai. Tinggi tanaman dapat berpengaruh langsung terhadap hasil kedelai (Sumarno dan Zuraida, 2006). Namun, rata-rata berat biji pada kedua varietas tidak menunjukkan perbedaan yang nyata seperti halnya pada faktor tinggi tanaman. Hal ini tidak lepas dari pengaruh pemberian pupuk nitrogen dan kemampuan fiksasi $\mathrm{N}_{2}$ Rhizobium sehingga nitrogen yang tersedia dalam tanah dapat memenuhi kebutuhan vegetatif tanaman yang akan berdampak kepada peningkatan produksi tanaman (Suryati dkk., 2009). Nitrogen yang diserap tanaman pada awal pertumbuhan akan dialokasikan pada batang dan daun, setelah terbentuk polong pada tanaman unsur tersebut selanjutnya dihimpun dalam kulit polong, semakin mendekati fase generatif akhir maka semakin banyak nitrogen yang terserap dalam biji (Adisarwanto, 2005).

Tabel 4 Rata-Rata Berat Biji Pertanaman (g) dan Per haktare (Ton) Kedelai pada 83 HST

\begin{tabular}{lcc}
\hline \multicolumn{1}{c}{ Perlakuan } & $\begin{array}{c}\text { Berat Biji } \\
\text { (g/tanaman) }\end{array}$ & $\begin{array}{c}\text { Berat Biji } \\
\text { (ton/Ha) }\end{array}$ \\
\hline Varietas & $23,48 \mathrm{a}$ & $3,01 \mathrm{a}$ \\
V1= Devon1 & $26,41 \mathrm{a}$ & $3,17 \mathrm{a}$ \\
V2= Dena 1 & $22,62 \mathrm{a}$ & $2,90 \mathrm{a}$ \\
Pupuk & $24,19 \mathrm{a}$ & $3,10 \mathrm{a}$ \\
P0 = Kontrol, & 25,57 a & $3,27 \mathrm{a}$ \\
P1= 1,32 g Urea/tanaman & 27,51 a \\
P2= 2,64 g Urea/tanaman & P3= 5,28 g Urea/tanaman \\
Keterangan: Angka yang diikuti huruf yang sama \\
\multicolumn{3}{c}{ dalam kolom, menunjukkan tidak } \\
\multicolumn{2}{c}{ berbeda nyata berdasarkan uji DMRT } \\
\multicolumn{2}{c}{ taraf 5\%. }
\end{tabular}

\section{KESIMPULAN}

Tidak ada pengaruh pemberian dosis pupuk urea terhadap pertumbuhan dan hasil tanaman kedelai. Perlakuan varietas berpengaruh terhadap pertumbuhan tanaman kedelai terhadap tinggi tanaman dan lebar daun dengan perlakuan terbaik adalah varietas Dena1 (V2) sementara pada perlakuan jumlah daun dan parameter hasil tidak memberikan pengaruh yang nyata. Sedangkan untuk perlakuan interaksi antara perlakuan varietas dengan pemberian pupuk urea terhadap pertumbuhan dan hasil tanaman kedelai tidak menunjukan interaksi yang berbeda nyata.

\section{DAFTAR PUSTAKA}

Adisarwanto, T. 2005. Kedelai Budidaya dengan Pemupukan yang Efektif dan Pengoptimalan Peran Bintil Akar Kedelai. Penebar Swadaya. Jakarta.

Arsyad, D. M., M. M. Adie, dan H. Kuswantoro. 2013. Perakiran varietas unggul kedelai spesifik agroekologi. Dalam Sumarno dkk (Eds.). Kedelai Teknik Produksi dan Pengembangan. Pusat 
Penelitian dan Pengembangan Tanaman Pangan. Jakarta.

Bachtiar., M. Ghulamahdi, M. Melati, D. Guntoro, dan A. Sutandi. Kebutuhan nitrogen tanaman kedelai pada tanah mineral dan mineral bergambut dengan budi gaya jenuh air. Penelitian Pertaniann Tanaman Pangan. 35(3): 217 - 227.

Badan Pusat Statistik (BPS). 2016. Produksi Tanaman Pangan Angka Tetap Tahun 2015. Badan Pusat Statistik, Jakarta.

Balai Penelitian Tanaman Aneka Kacang dan Umbi (Balitkabi). 2015a. Deskripsi Varietas Unggul Kedelai. Balitkabi, Malang.

Lina, S.B, M. Okazaki, D. S. Kimura, Y. Yano, K. Yonebayashi, M. Igura, M. A. Quevedo and A. B. Loreto. 2009. Nitrogen uptake by sago palm (Metroxylon sagu Rottb.) in the early growth stages. Soil Science and Plant Nutrition. 55: 123-144.

Marschner, H. 1986. Mineral Nutrition of Higher Plants. Academic Press. London.

Permanasari, I., M. Irfan dan Abizar. 2014. Pertumbuhan dan hasil kedelai (Glycine $\max$ (L.) Merill) dengan pemberian rhizobium dan pupuk urea pada media gambut. Jurnal Agroteknologi. 5(1): 29-34.

Salisbury, F.B., dan Ross, C. W. 1995. Fisiologi Tumbuhan Jilid 2 (penerjemah: Diah R.L., Sumaryono). ITB Press. Bandung:

Santana, F. P., M. Ghulamahdi, I. Lubis. Respons pertumbuhan, fisiologi, dan produksi kedelai terhadap pemberian pupuk nitrogen dengan dosis dan waktu yang berbeda. Jurnal Ilmu Pertanian Indonesia. 26(1): $24-31$.

Suhre, J. J., N. H. Weidenbenner, S. C. Rowntree E. W.Wilson, S. L. Naeve, S. P. Conley. 2014. Soybean yield partitioning changes revealed by genetic gain and seeding rate interactions. Agronomy Journal. 106: 1631-1642.

Sumarno dan Zuraida. 2006. Hubungan korelatif dan kausatif antara komponen hasil dengan hasil biji kedelai. Jurnal Penelitian Pertanian Tanaman Pangan. 25(1): 38-43.

Suryati, D., N. Susanti, dan Hasanudin. 2009. Waktu aplikasi pupuk $\mathrm{N}$ terbaik untuk pertumbuhan dan hasil kedelai varietas Kipas Putih dan Galur 13 ED. Aleta Agrosia 12(2):204-212.

Susanto, G. W. A. dan Nugrahaeni, N. 2017. Pengenalan dan Karakteristik varietas unggul kedelai. Dalam Nugrahaeni, N., dkk (Eds). Bunga Rampai Teknik Produksi Benih Kedelai. IAARD Press. Jakarta.

Taufiq, A. dan Sundari, T. 2012. Respons tanaman kedelai terhadap lingkungan tumbuh. Buletin Palawija. 23: 13 - 26.

Triadiati, N. R. Mubarik dan Y. Ramasita. 2013. Respon pertumbunan tanaman kedelai terhadap Bradyrhizobium japonicum toleran masam dan pemberian pupuk di tanah masam. J. Agron. Indonesia. 41(1): 24-31.

Widiastuti, E. dan Latifah, E. 2016. Keragaan pertumbuhan dan biomassa varietas kedelai (Glycine $\max (\mathrm{L})$ ) di lahan sawah dengan aplikasi pupuk organik cair. Jurnal Ilmu Pertanian Indonesia. 21(2): 90 - 97.

Winarso, B. 2013. Kebijakan pengembangan komoditas tanaman pangan dalam mendukung program master plan percepatan dan perluasan pembangunan ekonomi indonesia (MP3EI) studi kasus di Propinsi Gorontalo. Jurnal Penelitian Pertanian Terapan. 13 (2): 85-102.

Yuliawati, T., T. K. Manik dan R. A. B. Rosadi. 2014. Pendugaan kebutuhan air tanaman dan nilai koefisien tanaman (Kc) Kedelai (Glycine max (L) Merril) 
varietas tanggamus dengan metode lysimeter. Jurnal Teknik Pertanian Lampung. 3(3): 233-238.

Zahrah, S. 2011. Respon berbagai varietas kedelai (Glycine max (L) Merril) terhadap pemberian pupuk NPK organik. J. Teknobiol. 2(1): 65 - 69 . 